\title{
ETIOLOGY OF CANINE OTITIS MEDIA AND ANTIMICROBIAL SUSCEPTIBILITY OF COAGULASE-POSITIVE STAPHYLOCOCCI IN FORTALEZA CITY, BRAZIL
}

\author{
Lis Christina de Oliveira' ${ }^{1 *}$; Carlos Artur Lopes Leite ${ }^{2}$; Raimunda Sâmia N. Brilhante ${ }^{3}$; Cibele Barreto M. Carvalho ${ }^{1}$ \\ ${ }^{1}$ Departamento de Patologia e Medicina Legal, Laboratório de Microbiologia Universidade Federal do Ceará, Fortaleza, CE, \\ Brasil; ${ }^{2}$ Departamento de Medicina Veterinária, Universidade Federal de Lavras, Lavras, MG, Brasil; ${ }^{3}$ Departamento de Patologia \\ e Medicina Legal, Centro Especializado em Micologia Médica, Universidade Federal do Ceará, Fortaleza, CE, Brasil
}

Submitted: August 09, 2005; Returned to authors for corrections: November 10, 2005; Approved: February 26, 2006

\section{SHORT COMMUNICATION}

\begin{abstract}
This study evaluated the middle ear microbiota and antimicrobial susceptibility patterns from strains isolated from dogs with otitis media. A total of 62 dogs obtained from Zoonoses Control Center of Fortaleza City Ceará State / Brazil were studied over a 10-month period (August/2003 to June/2004). Of the total, 46.8\% $(n=30)$ of the animals were positive for otitis media and the infection was monomicrobial in $76.6 \%$ of them. The most frequent isolated agents were coagulase-positive Staphylococci (CPS-55\%) and Pseudomonas sp $(10 \%)$. For $S$. intermedius $(\mathrm{n}=13)$ and $S$. aureus subsp aureus $(\mathrm{n}=9)$, respectively, the greater resistance rates were observed using penicillin $\mathrm{G}$ (30.76\% and $44.44 \%$ ), ampicillin ( $7.69 \%$ and $44.44 \%$ ), erythromycin (23.07\% and $44.44 \%$ ), clindamycin (23.07\% and $44.44 \%)$ and thrimethropim/sulfamethoxazol (15.38\% and $33.33 \%)$.
\end{abstract}

Key words: otitis media, dogs, Staphylococci, antimicrobials

In the animal practice, otitis media is a common disease and often a frustating problem. It is difficult to diagnose with the work-up being both costly and, at times invasive. In dogs the most common cause of otitis media is an extension from otitis externa and bacterial infection is more common than yeast infections (9). Cole et al.(2) compared the results of bacteriologic cultures from middle ear and the horizontal ear canal and identical isolates were found in only $10.5 \%$ of the ears. Sometimes empiric therapy is necessary, mainly in therapeutic-centers where microbiology laboratories are not available and when the invasive diagnostic is impossible to be done, as in the majority of cases of otitis media. Although predictable patterns exist, significant variation in resistance rates between medical institutions or geographical areas have been reported. Considering the great importance of the middle ear otitis in the veterinarian clinic and the few microbiological studies, the present study had as purposes to determine the etiology of canine otitis media and to evaluate the susceptibility profile of the prevalent bacteria.
Over a period of 10 months (August/2003 to June/2004), 62 stray dogs were investigated. The dogs were obtained from Zoonoses Control Center of Fortaleza-Ceará. The criteria for the inclusion in the study were: otoscopic abnormal or ruptured tympanic membranes, otitis externa (with erythema, ulceration of the tegument, otorrhoeae and foreign bodies). The exudates of the middle ear were obtained after ear canal ablation and lateral bulla osteotomy. A $0.5 \mathrm{~mL}$ of BHI was injected with a syringe in the middle ear and the aspirated material was sent to the laboratory. Total transfer time to the laboratory was no longer than two hours. The specimens were inoculated onto blood agar (BAP), MacConkey agar and Brain Heart Infusion broth (BHI) and incubated at $37^{\circ} \mathrm{C}$ in aerobiosis. The sample obtained for anaerobic culture was inoculated into supplemented Brain Heart Infusion agar (with 5\% of sheep blood, hemine $(5 \mu \mathrm{g} / \mathrm{mL}$ ) and menadione $(1 \mu \mathrm{g} / \mathrm{mL})$ - and Bacteroides Bile Esculin agar and incubated at $35-37^{\circ} \mathrm{C}$ in anaerobiosis. For fungal isolation, the samples were inoculated into Sabouraud glucose agar

*Corresponding Author. Mailing address: Rua Joaquim Torres, 941, Joaquim Távora. 60135-130, Fortaleza, CE, Brasil. Tel.: (+5585) 3264-1075, Fax: (+5585) 3264-4703. E-mail: lisveterinaria@yahoo.com.br or liscristina@agricultura.gov.br 
(supplemented with $0.05 \%$ of cycloheximide and $0.05 \%$ of chloramphenicol). The microorganisms isolated were identified by routine biochemical methods (10). Antimicrobial susceptibility testing was done for all isolated strains by agar diffusion method (11). Staphylococcus aureus ATCC 25285 was used as quality control. According to NCCLS (1997) recommendation, the antimicrobial agents tested were: penicillin $\mathrm{G}$, ampicillin, cefalotin, cefoxitin, imipenem, oxacillin, ticarcillin, amikacin, kanamycin, gentamicin, neomycin, tobramycin, ciprofloxacin, enrofloxacin, clindamycin, erythromycin, tetracycline, chloramphenicol, thrimethropim/sulfamethoxazol and vancomycin.

Of the total, $46.8 \%$ (30) of the animals were positive for otitis media and the infection was monomicrobial in $76.7 \%$ of them. The most frequent isolated agents were coagulase-positive Staphylococci (55.0\%) and Pseudomonas sp (10.0\%) (Table 1). The top two pathogens accounted for $65.0 \%$ of all isolates. Concerning to CPS, S. intermedius strains $(\mathrm{n}=13)$ showed low resistance to ampicillim (7.69\%) and tetracycline (7.69\%) and moderate to high resistance to thrimethropim/sulfamethoxazol $(15.38 \%)$, clindamycin $(23.07 \%)$, erythromycin $(23.07 \%)$ and penicillin G (30.76\%). S. aureus subsp aureus strains seemed more resistant (Table 2). For this specie, moderate resistance was observed using cefalotin/ cefoxitin/ ticarcillin/ kanamycin and tobramycin (11.11\% for all them). High resistance was obtained testing gentamycin/ neomycin and thrimethropim/ sulfamethoxazol (33.33\%) and penicillin G/ ampicillin/ clindamycin and erythromycin (44.44\%). Oxacillin resistance was recovered in one $S$. aureus subsp aureus strain. All CPS were uniformly susceptible to fluorquinolones and vancomycin.

In the few studies about otitis media in dogs, S. intermedius, yeast and Pseudomonas sp have been isolated. The results of this study are similar to other described in the literature $(2,3,4)$. Although some studies have considered cogulase-negative Staphylococci to be the main bacterial agent in canine otitis (6), in the present study CPS were the most common isolated agents. These results are similar to others $(2,12)$. There has been increasing interest in S. intermedius from dogs, considering the evident zoonotic potential of this specie as described in the literature (13).

There have been many studies of the in vitro effect of antimicrobial agents against CPS strains isolated from dogs. These studies are of great importance in the selective use of chemotherapeutics. In this study, moderate to high resistance to penicillin $\mathrm{G}$, ampicillin, erythromycin, clindamycin and tetracycline were detected. As expected, a high level of resistance to penicillin and ampicillin was observed, because of $\beta$ lactamases produced by $S$. intermedius and S. aureus. However, the results showed a lower resistance than that related by Magalhães et al. (7) and Boerlin et al. (1). Origin of the dogs (stray dogs) may account for this difference in resistance rates.

Macrolides are widely used in veterinary medicine for the treatment of bacterial infections, including $S$. intermedius
Table 1. Microorganisms isolated from dogs $(n=30)$ with otitis media in Zoonoses Control Center - Fortaleza City / Brazil (August/2003 - June/2004).

\begin{tabular}{cl}
\hline Sample & \multicolumn{1}{c}{ Isolation } \\
\hline 01 & Pseudomonas sp \\
02 & S. intermedius + Streptococcus G group + \\
& Micrococcus \\
03 & S. xylosus \\
04 & S. xylosus \\
05 & C. albicans \\
06 & S. intermedius \\
07 & S. int + Pseudomonas sp \\
08 & S. intermedius \\
09 & S. intermedius \\
10 & E. faecalis \\
11 & S. intermedius + Bacillus sp + Pseudomonas sp \\
12 & S. intermedius + Pseudomonas sp \\
13 & S. intermedius \\
14 & S. intermedius \\
15 & S. aureus subsp aureus \\
16 & S. intermedius \\
17 & S. aureus subsp anaerobius \\
18 & S. aureus subsp anaerobius \\
19 & S. aureus subsp aureus \\
20 & S. aureus subsp aureus \\
21 & S. aureus subsp aureus \\
22 & S. intermedius \\
23 & S. schleiferi \\
24 & S. aureus subsp aureus + \\
& K. pneumoniae + E. cloacae \\
25 & S. aureus subsp aureus \\
26 & S. aureus subsp aureus + \\
& M. pachydermatis + Candida sp \\
27 & S. aureus subsp aureus \\
28 & S. aureus subsp aureus \\
29 & S. intermedius \\
30 & S. intermedius \\
\hline & \\
&
\end{tabular}

resistant to penicillins. Our results for macrolides are similar to those obtained by other authors (5) but differ from the other ones (7). This discrepancy may be due to regional differences in the use of antimicrobial agents.

Resistance to fluorquinolones was not observed for CPS in this study. Many studies had showed the efficiency of these antimicrobials for canine isolates (5). Concerning to oxacillin, only one resistant strain was recovery. This result is similar to that described for Lilenbaum et al. (6) that showed $95.4 \%$ of susceptibility to oxacillin in Staphylococci strains isolated from dogs. 
Table 2. Resistance rates to antimicrobials of $S$. intermedius and $S$. aureus subsp. aureus isolated from canine otitis media in Zoonoses Control Center - Fortaleza City / Brazil (August/ 2003 - June/2004).

\begin{tabular}{lcc}
\hline Antimicrobial & S. intermedius & $\begin{array}{c}\text { S. aureus } \\
\text { subsp aureus }\end{array}$ \\
\hline Penicillin G & $30.76 \%$ & $44.44 \%$ \\
Ampicillin & $7.69 \%$ & $44.44 \%$ \\
Cefalotin & - & $11.11 \%$ \\
Cefoxitin & - & $11.11 \%$ \\
Imipenem & - & - \\
Oxacillin & - & $11.11 \%$ \\
Ticarcillin & - & $11.11 \%$ \\
Amikacin & - & $22.22 \%$ \\
Kanamycin & - & $11.11 \%$ \\
Gentamycin & - & $33.33 \%$ \\
Neomycin & - & $33.33 \%$ \\
Tobramycin & - & $11.11 \%$ \\
Ciprofloxacin & - & - \\
Enrofloxacin & - & - \\
Clindamycin & $23.07 \%$ & $44.44 \%$ \\
Erythromycin & $23.07 \%$ & $44.44 \%$ \\
Tetracicline & $7.69 \%$ & $22.22 \%$ \\
Chloramphenicol & - & - \\
Thrimethropim/ & $15.38 \%$ & $33.33 \%$ \\
sulfamethoxazol & & - \\
Vancomycin & - & \\
\hline
\end{tabular}

(-) No resistant strain recovery.

In veterinary dermatology as in other spheres of human and veterinary medicine, the driving forces of resistance are exposure of bacteria to antibiotics and to mixed microbial populations. In animals as in humans the use of antibiotics not only causes an increase of resistance in pathogenic bacteria, but also in the endogenous flora of these animals. Resistant bacteria from animals, zoonotic bacteria or intestinal flora can infect or reach the human population not only by direct contact, but also via food products of animal origin (14). In this study classic pathogenic bacteria and multiresistant coagulase positive Staphylococci were recovered. Antibiotic resistant bacteria are associated with the failure of treatment and increased mortality and morbidity. In this country, as in other developing countries there is widespread and uncontrolled use of antibiotics, mainly in the veterinarian clinic. Doctors' working conditions and patients attitudes to antibiotics, cultural and social factors, health-care system are indirect factors that can also contribute to the antimicrobial resistance (4). In dogs with otitis media, culture and susceptibility testing from middle ear exudates are recommended to aid in the selection of an appropriate systemic antimicrobial agent. In the absence of a microbiologic diagnostic, the choice of the antibiotic used is empiric. Empiric treatments hamper the implementation of treatment strategies because the resistance varies from region to region. However, when this is not possible in the clinic, periodic studies, in order to monitorizing the antimicrobial resistance should be done.

\section{ACKNOWLEDGEMENTS}

This work was supported by grants of the Conselho de Aperfeiçoamento e Pesquisa (CAPES). The authors thank Terezinha de Jesus Santos Rodrigues and José Olavo de Morais for technical help and the Zoonoses Control Center.

\section{RESUMO}

\section{Etiologia da otite média canina e susceptibilidade a antimicrobianos de Staphylococcus coagulase-positiva em Fortaleza, Brasil}

O presente trabalho avaliou a microbiota do ouvido médio e os perfis de susceptibilidade a antimicrobianos de cepas isoladas de cães com otite média. Um total de 62 cães obtidos no Centro de Controle de Zoonoses de Fortaleza - Ceará / Brasil foram estudados no período de 10 meses (agosto/2003 a junho/ 2004). Do total de animais, $46.8 \%(\mathrm{n}=30)$ foram positivos para otite media e a infecção envolvida era monomicrobiana em 76,6\% dos casos. Os agentes isolados com maior frequência foram Staphylococcus coagulase-positiva (CPS-55\%) e Pseudomonas sp (10\%). Considerando-se S. intermedius $(\mathrm{n}=13)$ e S. aureus subsp aureus $(\mathrm{n}=9)$, respectivamente, as mais elevadas taxas resistência foram observadas frente a: penicilina $\mathrm{G}(30,76 \%$ e $44,44 \%)$, ampicilina $(7,69 \%$ e $44,44 \%)$, eritromicina $(23,07 \%$ e $44,44 \%)$, clindamicina $(23,07 \%$ e $44,44 \%)$ e trimetropim/ sulfametoxazol $(15,38 \%$ e $33,33 \%)$.

Palavras-chave: otite média, cães, Staphylococcus, antimicrobianos

\section{REFERENCES}

1. Boerlin, P.; Burnens, A.P.; Frey, J.; Kuhnert, P.; Nicolet, J. Molecular epidemiology and genetic linkage of macrolide and aminoglycoside resistance in Staphylococcus intermedius of canine origin. Vet. Microbiol., 79, 155-169, 2001.

2. Cole, L.K.; Kwochka, W.K.; Kowalski, J.J.; Hillier, A. Microbial flora and antimicrobial susceptibility patterns of isolated pathogens from the horizontal ear canal and middle ear in dogs with otitis media. J. Am. Vet. Med. Assoc., 212(4), 534-538, 1998.

3. Colombini, S.; Merchant, S.R.; Hosgood, G. Microbial flora and antimicrobial susceptibility patterns from dogs with otitis media. Vet. Derm., 11, 235-239, 2000. 
4. Hart, C.A.; Kariuki, S. Antimicrobial resistance in developing countries. Brit. Med. J., 317, 647-650, 1998.

5. Kiss, G.; Radvayi, S.Z.; Szigeti, G. New combination for the therapy of canine otitis externa. I. Microbiology of otitis externa. J. Small Anim. Pract., 38(2), 51-56, 1997.

6. Lilenbaum, W.; Veras, M.; Blum, E.; Souza, G.N. Antimicrobial susceptibility of Staphylococci isolated from otitis externa in dogs. Lett. Appl. Microbiol., 31, 42-45, 2000.

7. Magalhães, M.J.; Silva, N.; Marques Jr, A.P. Otite externa em cães atendidos no Hospital Veterinário da UFMG: etiologia, frequiência e sensibilidade a antibióticos. Arq. Bras. Medic. Vet. Zoot., 37(4), 333341,1985

8. Matsuda, H.; Tojo, M.; Fukui, K. The aerobic bacterial flora of the middle and external ears in normal dogs. J. Small Anim. Pract., 25, 269-274, 1984.

9. Murphy, K.M. A review of techniques for the investigation of otitis externa and otitis media. Clin. Techn. Small Anim. Pract., 16(3), 236-241, 2001
10. Murray, P.R.; Baron, E.Jo.; Jorgensen, J.H.; Pfalller, M.A. Yolken RH. MANUAL OF CLINICAL MICROBIOLOGY. $8^{\text {th }}$ ed. ASM PRESS, 2003.

11. NCCLS. 1997. Performance Standards for Antimicrobial Disk and Dilution Susceptibility Tests for Bacteria Isolated from Animals; Tentative Standard. NCCLS Document M31-T. Wayne Pennsylvania, 1987, USA.

12. Nobre, M.O.; Castro, A.P.; Nascente, P.S.; Ferreiro, L.; Meireles, M.C.A. Occurrency of Malassezia pachydermatis and other infectious agents as cause of external otitis in dogs from Rio Grande do Sul, Brazil (1996/1997). Braz. J. Microbiol., 32(3), 243-247, 2001.

13. Talan, D.A.; Staatz, D.; Staatz, A.; Goldstein, E.J.C.; Singer, K.; Overturf, G.D. Staphylococcus intermedius in canine gingival and canine-inflicted human wound infections: laboratory characterization of a newly recognized zoonotic pathogen. J. Clin. Microbiol., 27(1), 78-81, 1989.

14. Van den Bogaard, A.E.; Stobberingh, E.E. Epidemiology of resistance to antibiotics. Links between animals and humans. Int. J. Ant. Agents, $14,327-335,2000$ 